\title{
公立小学校におけるクラスルームとユニットプランに関する研究 米国の学校建築に関する研究
}

\section{CLASSROOM AND UNIT-PLAN OF ELEMENTARY SCHOOLS IN THE US}

Studies on school facilities in the US

\author{
鈴木 賢一*1, 柳 澤 要*2, 上野＼cjkstart淳*3 \\ Ken-ichi SUZUKI, Kaname YANAGISAWA and Jun UENO
}

\begin{abstract}
The purpose of this paper is to analyze the diversity of the classroom and unit-paln of elementary schooks in the US. We investigated thirteen elementary schools in detail by the field survey.

The results are summarized as follows ; 1) Unit-plan of classrooms may be divided into two types, closeplaned and open-planed type. 2) The close-planed type can be cla.sified into the unit with common space and without it. The open-planed type can be classified into the loose-divided and non-divided type. 3)The investigated classrooms are $3.3-5.0 \mathrm{~m}^{2} /$ pupil in area. They have various shapes, triangle, square, pentagon, hexagon and L-shaped. They face not only south but also various clirections.
\end{abstract}

Keywords : school facilities in the US, elementary school, learning space, classroom, open space 米国の”咬建築、小学校、学習スペース、クラスルーム、オープン・スペース

\section{1. 研究の目的と方法 \\ 1.1 研究の目的}

米国において教育は州の責任事項であり、しかもその多くの

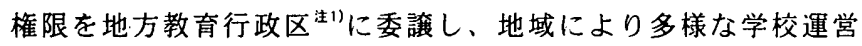
が行われている。歴史的にも、1940年代に近代学校建築が登 場以降、時代にふさわしい学校の在り方が試みられてきた注2)。 このように地域的、歴史的に教育に関する多様な方法論が試さ れ、それを支える学校建築の在り方もきわめて多様である。

日本と米国では教育の背景となる文化や制度の違いは大きい が、米国で展開される多様な方法論について様々な視点から詳 しい分析を行っておくことは、学校の画一的な建築計画が繰り 返される我が国の現状に資するところは大きいと考えら机る。 本論文は、米国の学校建築に関して小学校のクラスルームに焦 点をあて分析を行うものである。すなわち、児童の学習や生活 の拠点となる最も重要な単位空間である小学校のクラスルーム 趈りの多様な試みの現状を分析し把握することを目的とする。

\section{2 研究の方法}

米国の小学校建築に関する主要な文献 ${ }^{(1)-8)}$ をとに、近代学校建築 の登場する1940年代から90年代までに建設されたうち、施設夕イ プ、教育・運営タイプ、規模の異なる学校を選択し、現地を訪問し
実態を把握した。こ抽のデータを基に、まずクラスルームに関わ る平面構成の分類在行う。さらにタイブ別に家具レイアウトやコ 一ナ゙一性、使わ扒方の実態在概観し、クラスルームの規模と密 度による面積水準や、方位や形態の特徵を明らかにする。

調查は1997年 5 月から 6 月にかけて、米国の教育先進地とさ打る 中西部から東部にある中学、高校を含さ 30 校以上について現地調查 在実施したが、ここではクラススペース迴りの平面構成について分 析価值のある公立小学校13校在対象とする注3)（表1）。

なお、現地での調查方法と内容は以下の通りである。

1）施設概要及び教育ブログラム調查：学校敷地及び校舍在見て歩

き、計画上の特徵を把握した。学校の概要、学習スベース、教育う ログラム、使われ方に関し、て予好準備した調查シート基に教師に ヒアリングを実施した。なお事前に平面図などの資料在参照した。

2 ) 授業の観察調査: 許可の得ら㧈た授業の展開の様子在觀察し

た。適宜写真撮影、ビデオ撮影を行なった。

3）レイアウト調查: 調查校の特徵を表わ寸と考えら才る典型的ク ラスルームやその他学習スペースの家具レイアウト在調査しだ(

$$
\text { 2. クラスルームとユニットの類型 }
$$

\section{1 調查校の学年配置}

学校の空間構成においては、同じ学年や隣接する学年ごとに複数

*1 名古屋市立大学芸術_工学部生活環境デザイン学科 助教授・ 工博

名古屋大学大学院教育学研究科 非常勤講師

*2 千葉大学:工学部デザイン工学科 助教授・工博

*3 東京都立大学大学院建築学専攻 教授・工博

東京工業大学文教施設研究開発センタ- 非常勤講師
Assoc. Prof., School of Design and Architecture, Nagoya City Univ., Dr. Eng.

Assoc. Prof., Dept. of Design and Architecture, Chiba Univ., Dr. Eng.

Prof., Graduate School, Tokyo Metropolitan Univ., Dr. Eng. 
のクラスを集合させて空間的、平面的にあるまとまりを構成し、配 置計画の基本となるユニットとする方法がとら扎ることが多い。こ れを「クラスルームのユニットブラン」（以下ユニット）と呼ぶ。

調㚗校の学年配置を概锶してみると、学年融成については、幼稚 園（5歳、学校によっては4歳のPre-Kinderを受け入れている）から 4年生までの場合、5年生までの場合、もしくはわが国と同様6年生ま でと様々である。調䈏艾は、幼稚園（以下K）-6年生が 6 校、 $\mathrm{K}-5$ 年生が 6 校、K-4年生が 1 校であっだ ${ }^{\text {in } 5) 。 ~}$

さて、ユニットの学年構成に関しては以下のようなタイブが観察 された。1) 同一学年の複数クラスでユニット構成：例(1)Crow Island、(5)Southwood Glen、(7) Vinton ${ }^{\text {i:.) }}$ 、(8)Rawson, (11) Glenville、2）２学年でユニット構成：例(3)L.Frances Smith、(4) Clifty Creek、(6)Heathcote、(9Mt. Healthy、3) 低学年亡高学年 をフロアで分離 : 例(12)Deerwood、(2)6 to 6 Early Childhood、(10) Fodrea、4) すべてのユニットが幼稚園-6年生で螎成 : 例(13Valley Crossing Community、である。

2.2 クラスルームのユニットプランの分舁

クラスルームのユニットプランを以下の通り分類した（表 2 ）。

1）ユニットの構成の観点からクローズド型とオーブン型に分類 できる。クローズド型は、他から独立したクラスルームを基本にユ ニットを構成するタイプ、オーブン型は複数クラスが建築的に境界

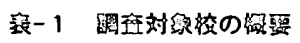

\begin{tabular}{|c|c|c|c|c|c|c|}
\hline 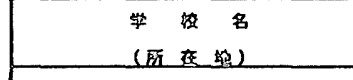 & 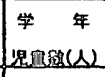 & $\begin{array}{l}\text { 察西和 } \\
\text { (mi) }\end{array}$ & 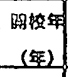 & $\begin{array}{l}\text { レイアの } \\
\text { 策啭 }\end{array}$ & 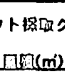 & 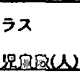 \\
\hline $\begin{array}{l}\text { (1) Crow Istand Elementary School } \\
\text { (Winnetka, llinois) }\end{array}$ & $\begin{array}{c}K-5 \text { th } \\
450\end{array}$ & 3,233 & 1940 & 1st & 104.4 & 24 \\
\hline $\begin{array}{l}\text { (2) } 6 \text { to } 6 \text { Eaty Cridhood Regional Masret } \\
\text { Schrool (Bridgeport, Connecticut) }\end{array}$ & $\begin{array}{c}\text { pre K - 4th } \\
220\end{array}$ & 3.716 & 1995 & 3rd & 96.9 & 20 \\
\hline $\begin{array}{l}\text { (3) L. Frances Smith Elementary School } \\
\text { (Columbus, Indiana) }\end{array}$ & $\begin{array}{c}\text { pre K-6th } \\
375\end{array}$ & 4.645 & 1970 & $\begin{array}{l}\text { 1st } \\
5 \text { th }\end{array}$ & $\begin{array}{l}83.6 \\
83.6 \\
\end{array}$ & $\begin{array}{l}18 \\
25\end{array}$ \\
\hline $\begin{array}{l}\text { (4) Clifty Creek Elementary School } \\
\text { (Columbus, Indiana) }\end{array}$ & $\begin{array}{c}K-6 \text { th } \\
570 \\
\end{array}$ & 5.295 & 1982 & 5th & 91.9 & 20 \\
\hline $\begin{array}{l}\text { (5) Southwood Glen Elementary School } \\
\text { (Franklin, Wisconsin) }\end{array}$ & $\begin{array}{c}\text { pre K - 6th } \\
412 \\
\end{array}$ & 6.596 & 1992 & $\begin{array}{l}\text { Sth } \\
\text { 3rd }\end{array}$ & $\begin{array}{l}83.8 \\
89.7 \\
\end{array}$ & $\begin{array}{r}25 \\
25 \\
\end{array}$ \\
\hline $\begin{array}{l}\text { (6) Heathcote Elementary School } \\
\text { (Scarsdale, New York) }\end{array}$ & $\begin{array}{c}K-5 \text { th } \\
320\end{array}$ & - & 1952 & $\begin{array}{l}\text { 2nd } \\
\text { 4th } \\
4 \text { th } \\
\end{array}$ & $\begin{array}{l}75.5 \\
75.5 \\
75.5 \\
\end{array}$ & $\begin{array}{l}22 \\
22 \\
22 \\
\end{array}$ \\
\hline $\begin{array}{l}\text { (2) Vinton Elementary School } \\
\text { (Lafayette, Indiena) }\end{array}$ & $\begin{array}{c}K-5 \text { th } \\
460\end{array}$ & 7,671 & 1994 & $\begin{array}{l}\text { 1st } \\
4 \text { th } \\
5 \text { th } \\
\end{array}$ & $\begin{array}{r}94.9 \\
94.9 \\
94.9 \\
\end{array}$ & $\begin{array}{l}22 \\
24 \\
20 \\
\end{array}$ \\
\hline $\begin{array}{l}\text { (8) Rawson Elementay School } \\
\text { (South Mitwaukee, Wisconsin) }\end{array}$ & $\begin{array}{c}K-5 \text { th } \\
465 \\
\end{array}$ & 7,667 & 1994 & $\begin{array}{l}5 \text { th } \\
5 \text { th }\end{array}$ & $\begin{array}{l}85.0 \\
85.0 \\
\end{array}$ & $\begin{array}{r}25 \\
25 \\
\end{array}$ \\
\hline $\begin{array}{l}\text { (9) At. Healthy Elementary School } \\
\text { (Columbus, Indiana) }\end{array}$ & $\begin{array}{c}\text { pre K - 6th } \\
245\end{array}$ & 4.645 & 1972 & $\begin{array}{c}t-1 \text { st } \\
2 n d-3 r d \\
4 t h-6 t h\end{array}$ & $\begin{array}{l}- \\
- \\
-\end{array}$ & $\begin{array}{l}17-23 \\
17-23 \\
17-23 \\
\end{array}$ \\
\hline $\begin{array}{l}\text { (1) Fodrea Community School } \\
\text { (Columbus, Indiana) }\end{array}$ & $\begin{array}{c}K-6 \text { th } \\
390\end{array}$ & 5,295 & 1973 & $\begin{array}{l}k-1 \text { st } \\
2 n d-3 r d \\
4 \text { th-6th }\end{array}$ & $\begin{array}{c}- \\
102.0 \\
84.0 \\
\end{array}$ & $\begin{array}{l}18 \\
18 \\
25 \\
\end{array}$ \\
\hline $\begin{array}{l}\text { (1) Glenville Elementary School } \\
\text { (Greenwich. Connecticut) }\end{array}$ & $\begin{array}{c}K-5 \text { th } \\
450 \\
\end{array}$ & - & 1975 & 2nd & 92.2 & 20 \\
\hline $\begin{array}{l}\text { (13) Deenwood Elementary School } \\
\text { (Eagan. Minnesota) }\end{array}$ & $\begin{array}{c}k-5 \text { th } \\
630 \\
\end{array}$ & 7,246 & 1987 & 1st & 79.0 & $22-26$ \\
\hline $\begin{array}{l}\text { (12) Valley Crossins Community School } \\
\text { (Woocoury, Minnesota) }\end{array}$ & $\begin{array}{c}\mathrm{K}-6 \text { th } \\
747\end{array}$ & 12,263 & 1996 & Ist-4th & 60.8 & $30-33$ \\
\hline
\end{tabular}

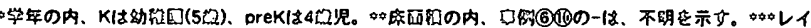

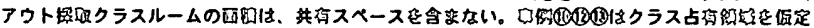

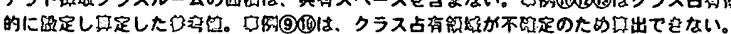

のない一体のオーブンスベースに配置さ报るタイブである。

2）クローズド型は、複数クラスが共有スペースを核としてュ ニットを構成するタイフと、共有スペースをもたないでユニットを 構成するタイブに分類できる。さらにクラスルームのタイフとして 各クラスがそれでけで完結している 1 クラス独立型クラスルーム と、2つのクラスルームが境界線上に固定的隔壁を設けないで一体 のスペースとして使用できる 2 クラス一体型に分䫛できる。

3）オープン型は、大規模なオーフンスペースをベースとする大 規模オーブン型と、クラス毎の領域が緩やかに分節化された分節才 ープン型に分けら机る。

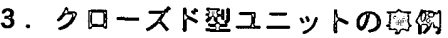

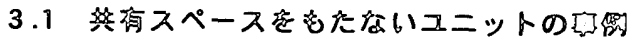

共有スペーースをもたないクローズド型ユニットの事例をう校六 す。1）全てのクラスルームが 1 クラス独立型：例 $\mathrm{Crow}$ Island、2) 全てのクラスルームが 2 クラス一体型 : (列包 6 to 6 Early Childhood、3）1 クラス独立型と2 クラスー一体型が同…… ニットの中に混在 : 例(3L. Frances Smith 、(4)Clifty Creek 、 5 Southwood Glen、である注7)。3）のタイブは同じ学校でタイプ 違うクラスルームが混在しており興味深い。

(1) Crow Island Elementary School, Illinois, 1940

クラスルームの平面形はワーク・スペースが付属した特徵あるL字 型である。中庭を介して隣接するクラスルーム相互の独立性は高 い。3面にとられた大きな開口部が特徵である。天井高は 9 feet（ $2.70 \mathrm{~m})$ で児童のスケールに台わせた空間である。1クラスの児童 は24人、面積に余裕のあるクラスル一ム内にブレイ・エリア、シッ

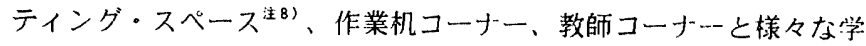
習に対応できるコーナ゙一在明確に位置付けている。

(2) 6 to 6 Early Childhood Regional Aagnet School, Connecricut, 1995

校舎全体は正方形のコンハクトな平面構成で、中央の附形ホール から周辺のクラスルームにアブローチ寸る。全てのクラスルームが 2 クラスでー・対となっており、可動間仕切りを開放す抽ば隣接教公 と一体化できる 2 クラス一体型である。レイアウトを採集した 3 年 生の事例は、正方形の対角楾上の可動間仕切りを䦥じて、3 角形の

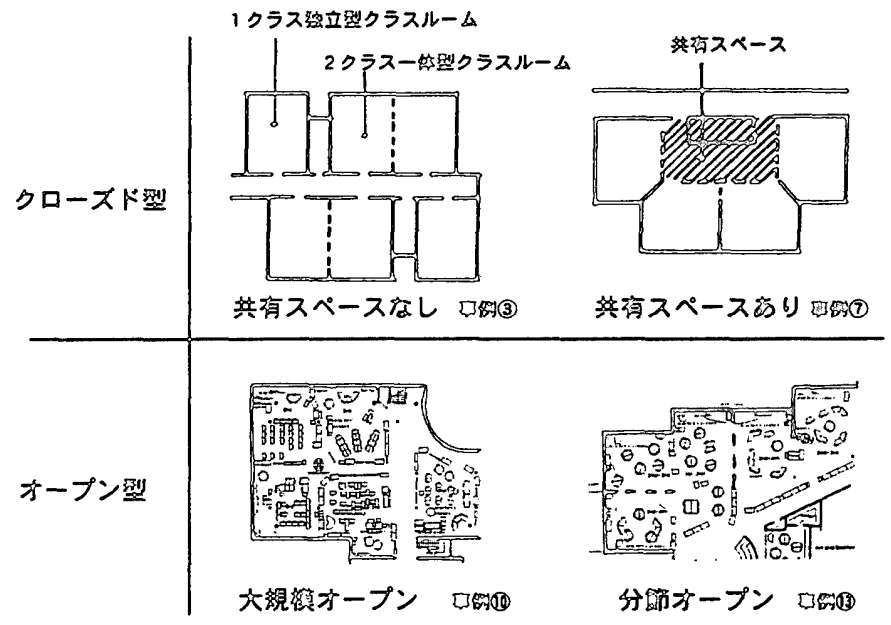

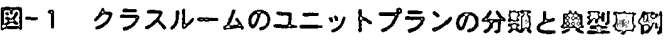


クラスルームとして使用しているユニークなケースである。

(3) L. Frances Smith Elementary School, Indiana, 1970 2 学年で構成される各ユニットには独立型と 2 クラスー体型が 2 つずつ混在する。2 クラス一体型クラスルームは、1990年に可動間 仕切りを導入している。レイアウトを採集したケースは可動間仕切
りを閉じ、1クラス分のスペースで 2 クラス台同のチーム・ティーチングを行っている。こうした活動は日常的で、 $83.6 \mathrm{~m}^{2} に 20$ 人前後 という面積的余裕がこうした活動を可能にしていると考えら才る。

(4) Clifty Creek Elementary School, Indiana, 1982

基本的に 2 つのクラスルームが一対となっているが、雨者が固定
(1) Crow Island Elementary School, Illinois, 1940

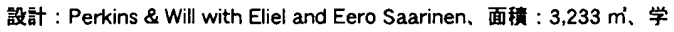

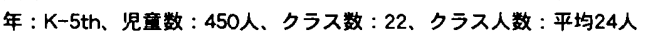

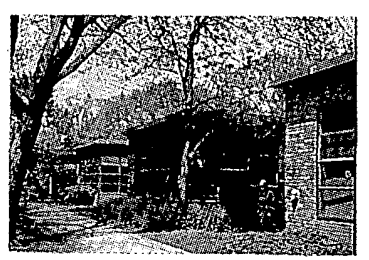

独立性の高いクラスルーム外視

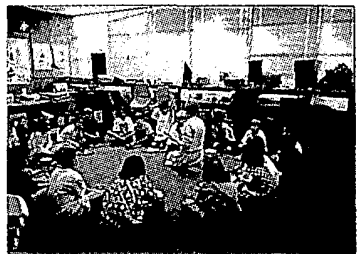

教師を团んでの学習風暴

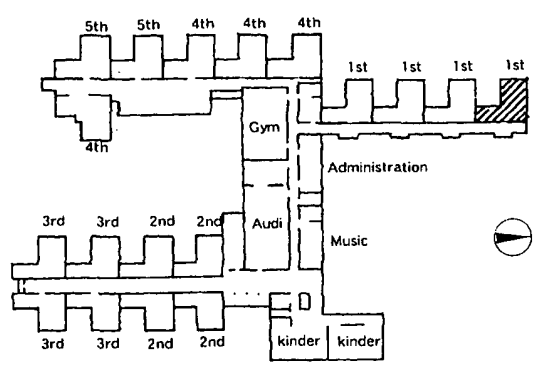

First Floor Plan (1/2500)

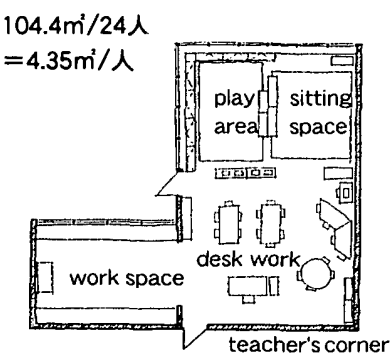

1 st grade Layout Map (1/400)

(2) 6 to 6 Early Childhood Regional Magnet School,Connecticut, 1995

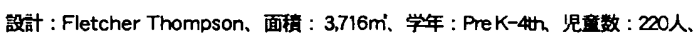
クラス人数 : 平均20人

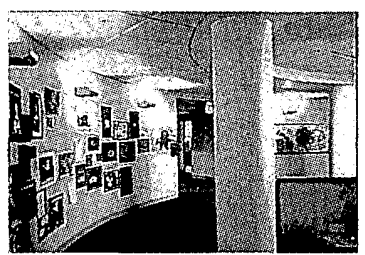

中央ホールのクラスルーム入ロ

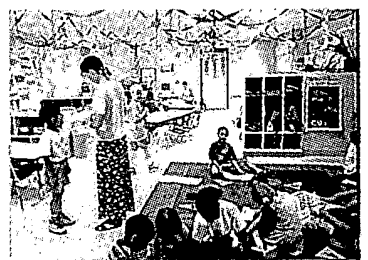

カーペット上ての学習活動
$\Theta$

$67.1 \mathrm{~m}^{\prime} / 20$ 人
$=3.36 \mathrm{~m}^{2} / \lambda$

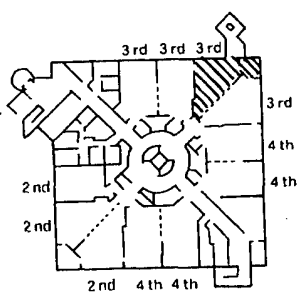

Second Floor Plan (1/2500)

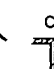

computer corner storage

(3) L.Frances Smith Elementary School, Indianal, 1970 設計:Johansen \& Bhavnani, 面糟:4,645m，学年:Pre K-6th，坚竡数:375人,クラ ス数: 16, クラス人数: $: K($ 平均18人), $2 n d-3 r d($ 平均22人), 4-6th(平均 25)人

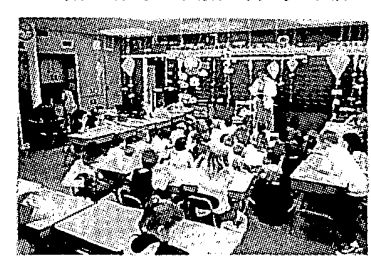

2 クラス合同の授業

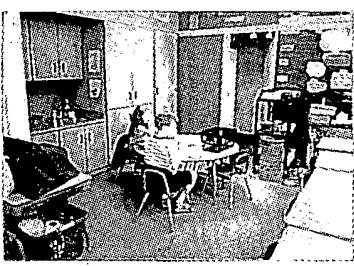

システム家具に柤み込まれた水週り

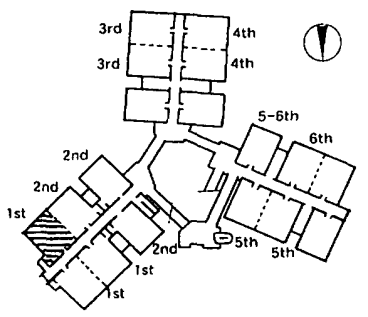

Second Floor Plan (1/2500)

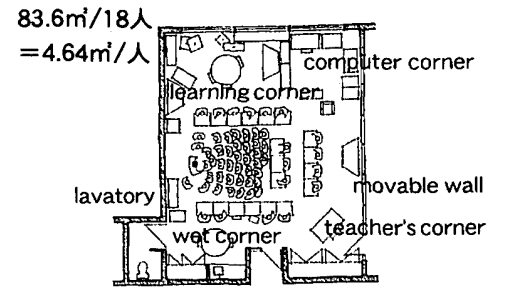

1 st grade Layout Map (1/400)

(4) Clifty Creek Elementary School, Indiana, 1982 設计 : Richard Meier \& Partners、面措 : $5,295 \mathrm{~m}$ 、学年 : K-6th、児童 数 : 570人、クラス数 : 25、クラス人数 : 19-22人
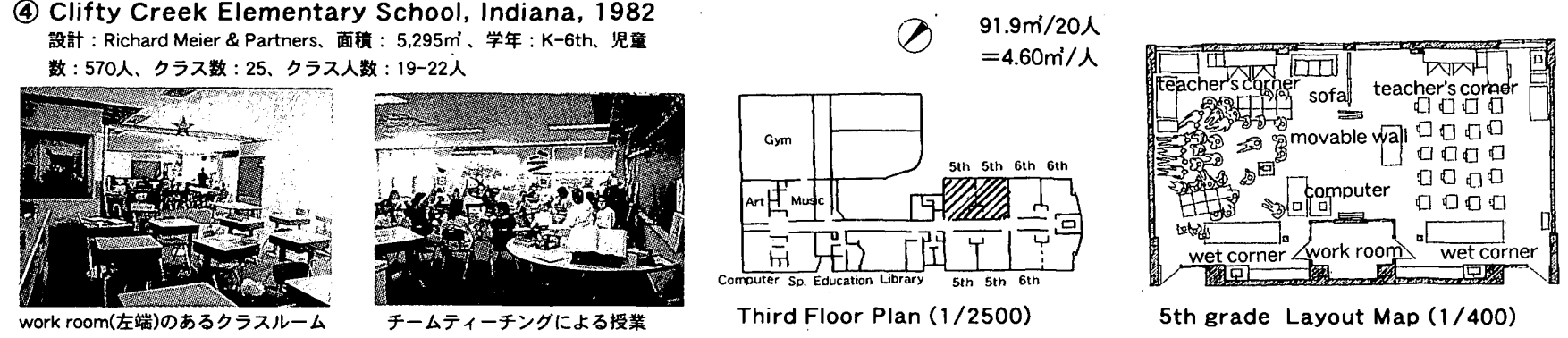

5th grade Layout Map $(1 / 400)$

(5) Southwood Glen Elementary School, Wisconsin, 1992

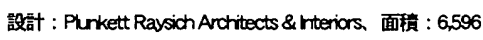
m、、学年: PreK(3-4yrs)-6th，児童数 : 412人、クラス

数 : 22、クラス人数: 平均 25 人

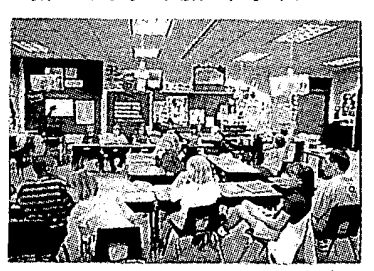

コの字型机配置での学習風量

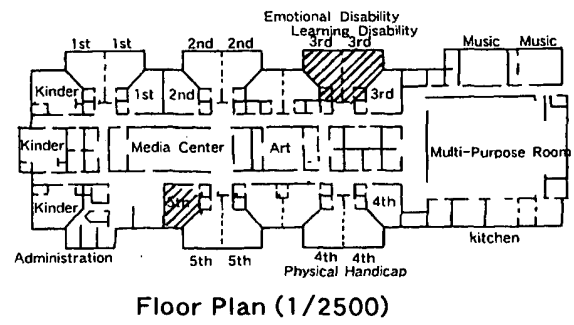

(1)

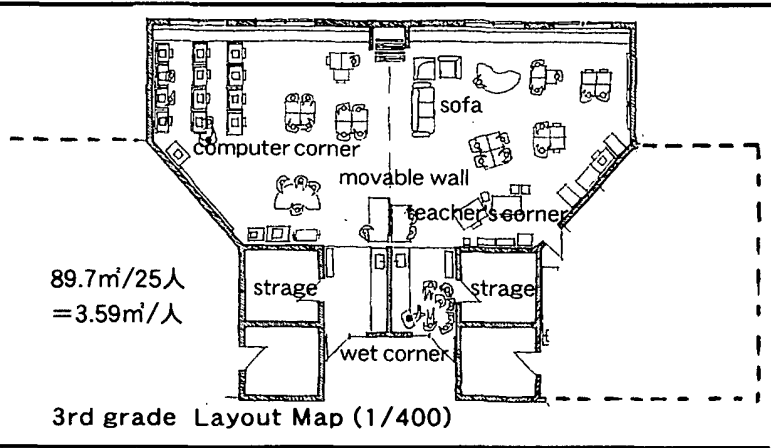

図 2 共有スペースをもたないクロースド型ユニットの事例 
壁で仕切られたユニットと、可動間仕切りを設けたユニットが混在 している。いず扎も $10 \mathrm{~m}$ 程度のガラス張りのワークルームを共有し ており、個人・グループの学習活動で利用される。

(5) Southwood Glen Elementary School, Wisconsin, 1992

3 つのクラスルームで構成したユニットをPOD（学年／教科など ある単位でまとまったグループのこと）と呼んでいる。このうち 2 クラスは可動間仕切りで一体化可能で、他は 1 クラス独立型であ る。調㚗例では可動間仕切りを開放し、様々な学習コーナーが全体 に広がっており、2 クラスが恒常的にスペースを一体化している様 子が伺われる。また、各POD間に学習障害児や情緒障害児のための 特矨学級が設置されているのが特徵である。

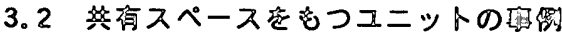

1960年代に設立さ扑た ⿹ 、8Rawson在取り上げた。クラスルームの形態や、共通スペース とのつながり方が各々特徵的である。

(6) Heathcote Elementary School, New York, 1952

6 角形の 4 つのクラスルームがopen hall と呼ばれる星形の共通ス ペースを取り囲む特徵的なユニットを構成している。クラスルーム は4 面が外部に面して開口部をもち開放的で求心性のある空間であ る。また、クラスルーム内部にはウェット・コーナーとデスク・ワ ーク・スペース、シッティング・スペース、教師コーナーなよ゙のコ 一ナーが形成されている。 open hall には、グルーブ用のテーブル

(6) Hearhcore Elemerary School, New York, 1962

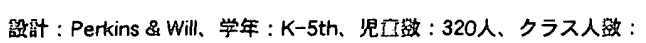
$K$ (平均18人)、1st-5th(平均22人)

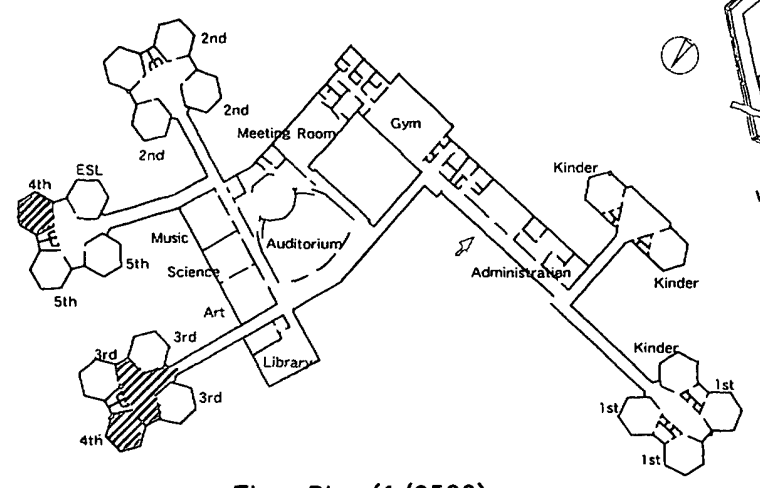

Floor Plan $(1 / 2500)$
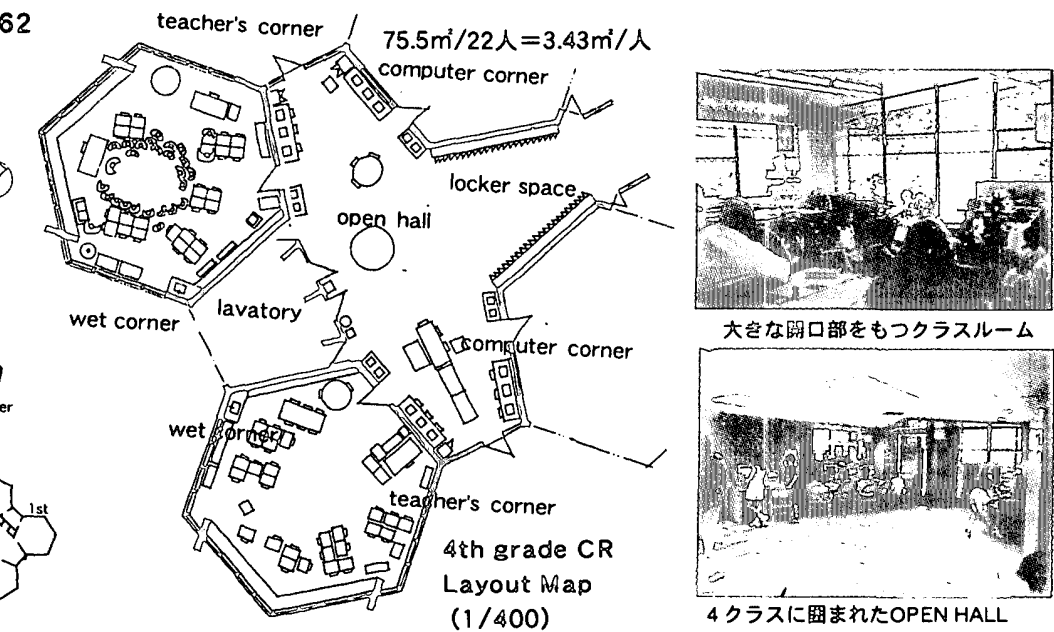

(7) Vinton Elementary School, Indiana, 1994

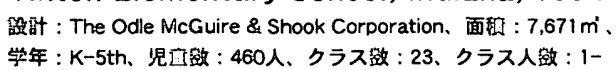
2nd(20-22人)、3-5th(25-26人)

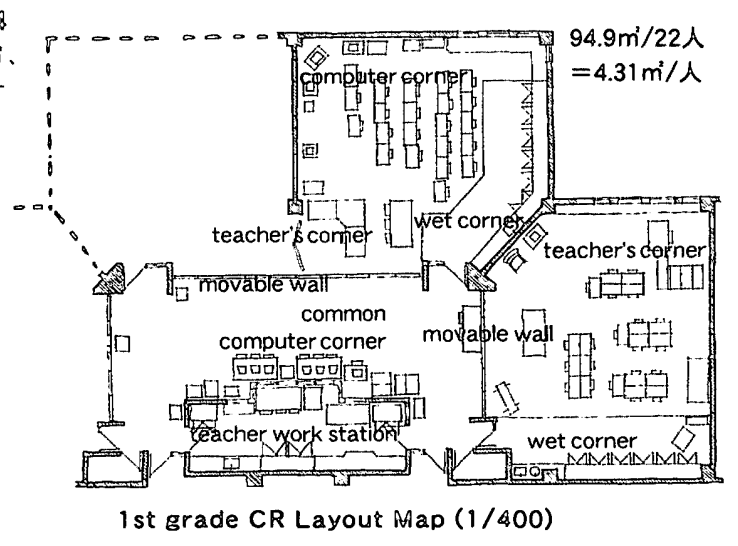

4クラスに四まれたOPEN HALL

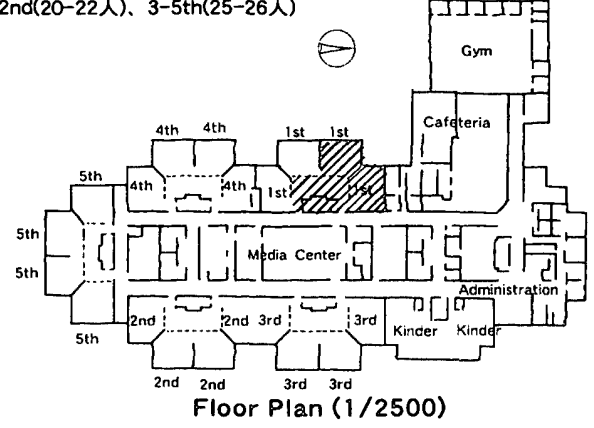

(8) Rawson Elementary School, Wisconsin, 1994 設䂥 : Plunkett Raysich Architects \& Interiors、面留 :

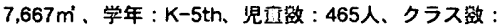
19、クラス人教 : 22-28人

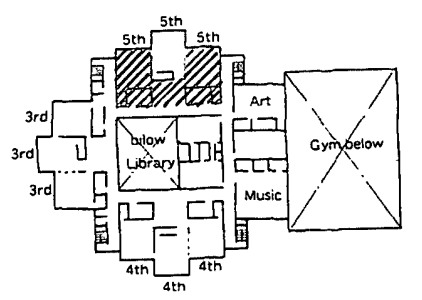

$\theta$

Second Floor Plan (1/2500)

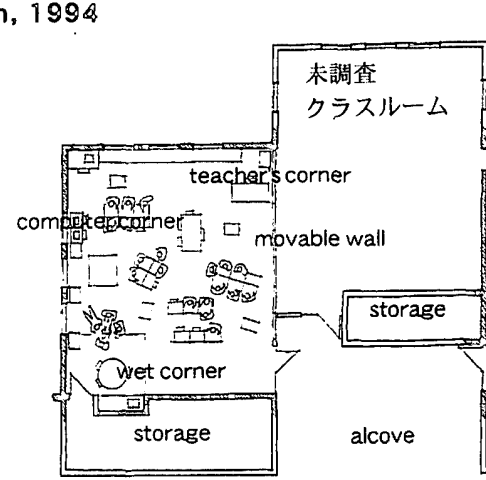

5th grade CR Layout Map (1/400)

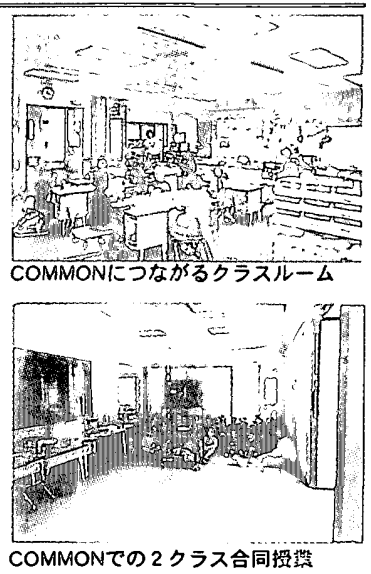

COMMONでの 2 クラス合同授管

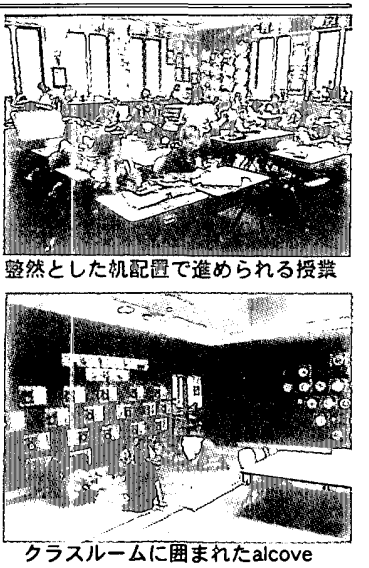

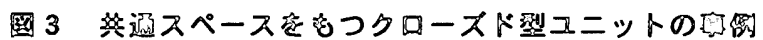


やコンピュータ、また実験・観察のコーナ゙ーなどが設けられ、クラ スルームの延長として利用されている。

(7) Vinton Elementary School, Indiana, 1994

4 つのクラスルームがCommonと呼ぶオープンスペースを取り囲 み、PODと呼ばれる学年のまとまりを形成している。各クラスルー ムとommonとの境界には可動間仕切があり、必要に応じて両者を一 体としたり分離したりできる。Commonにはコンピュータ・コーナ 一やグルーブ・ワーク用の自主学習用のコーナーが設けら扎てい る。中央部にガラス張りの教師用ワーク・ステーション（teacher work station）があり、教師の準備スペースの役割を担っている。

(8) Rawson Elementary School, Indiana, 1994

同学年の 3 クラスが共有スペース（alcove）を取り囲み、 HOUSE と呼ぶユニットを構成している。HOUSE 内の 3 つのクラ スルームのうち 2 つは可動間仕切りで仕切ら扎た 2 クラスー体型、 残りは 1 クラス独立型という組み合わせである。クラスルームは 各々ゆったりとした教材倉庫を付属している。alcove はグループで の学習や作品の展示などさまざまに利用されているが、ドア 1 枚の みでつながっており、空間的な連続感は弱い。

\section{3 クロースド型ユニットの使われ方の特徽}

共有スペースを持たない事例では、1 クラス独立型、2 クラス・ 体型のいずれて場台も、work spaceやwork room在付属させた り、隣接しで教材倉庫やトイレを設置するなど学習・生活の耐面に 対する建築的+ポートが充実している。2クラス一体型では 2 ク ス分のスペースに特徵的な学習コーナー一を有効に設け恒常的に一体 運営している様子がうかがわ扎る1クラス独立型に拀いてもチ‥么・ティーチングが展開される場面が観察され、クラス超えた学 習活動が珍しくない。

Open Hall、Common、Alcove 等の名称で呼ば扔る共有スペース を複数クラスが取り囲む事例では、共有スペースにコンピュータ・ コーナーや実験・観察コーナーなどが置か挑、クラスルームと不可 分の関係を保っている。こ㧈らはクラスとしての独立した運営を担 保しつつ、学年としての一体的領域を形成しているといえる。

また、ユニット内の共有スペースの有無に関わらず、クラスル‥ム内は、デスク・ワークのコーナ゙ーを中心に、コピュータ・コーナー、ウェット・コーナー、シッティング・スペース、リーディン グ・コーナー等、様々な学習コーナーを形成している。

(9) Mt. Healthy Elementary School, Indiana, 1972

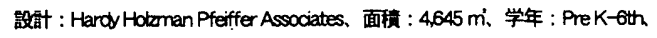
児䡤数 : 245人、クラス人数 : $17-23$ 人

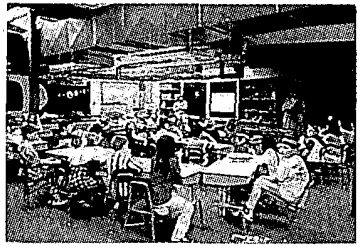

設備配䈏の露出したクラスルーム

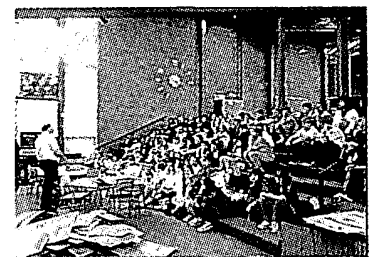

大階段を利用した合同授業
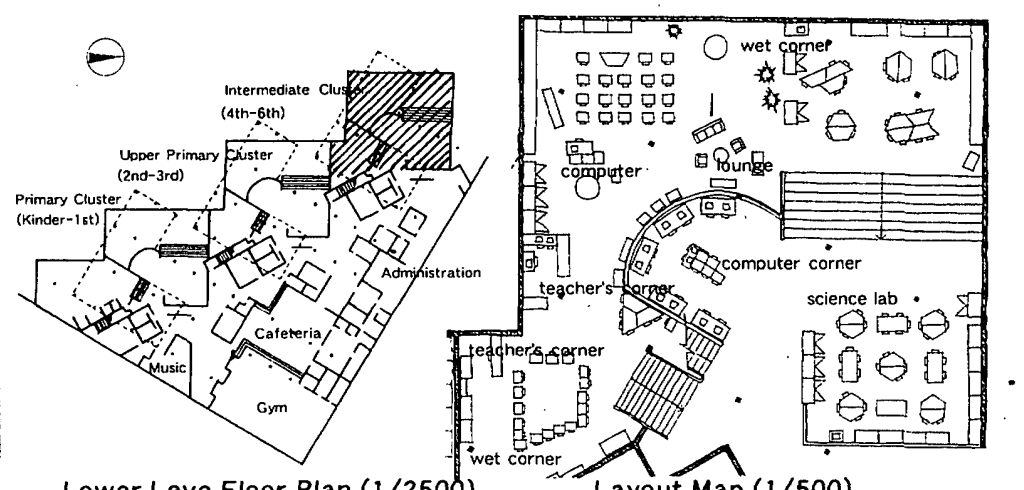

Lower Leve Floor Plan (1/2500) Layout Map (1/500)

(10) Fodrea Community School, Indiana, 1973

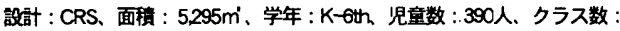
18. クラス人数: $\mathrm{K}-3$ th (平均 18 人) 、4-6th (平均25人)

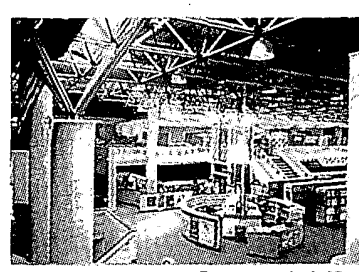

スペースフレームで錬われた大空間

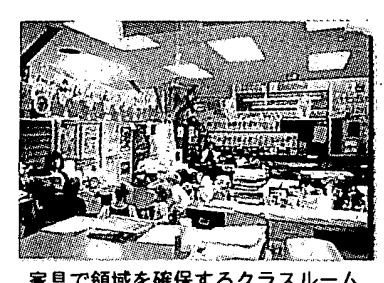

家具で領域を確保するクラスルーム

(11) Glenville Elementary School, Connecticut, 1975

学年 : K-5th，児童数 : 450 人、クラス数 : $21 、$ クス人数 : 平均20人

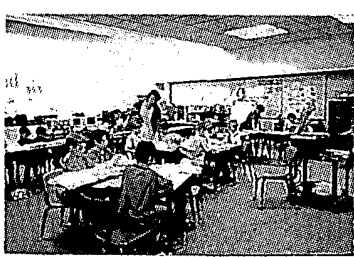

間接探光のクラスルーム

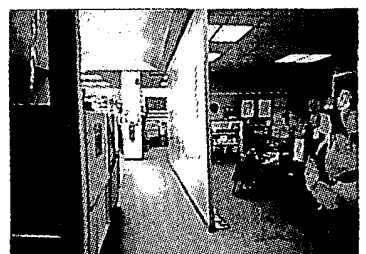

オープンスペースに罗入された間仕切
(1)

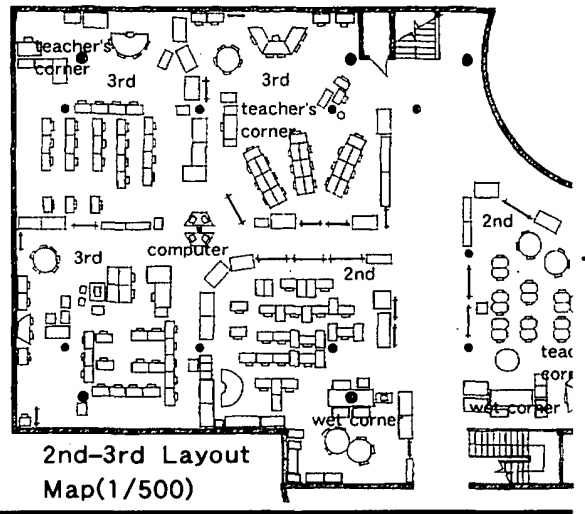

$92.2 \mathrm{~m}^{\prime} / 20$ 人 $=4.61 \mathrm{~m}^{\prime} /$ 人

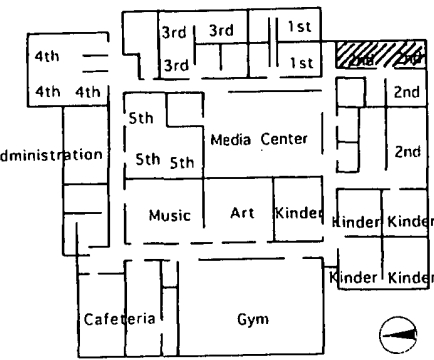

First Floor Plan (1/2500)

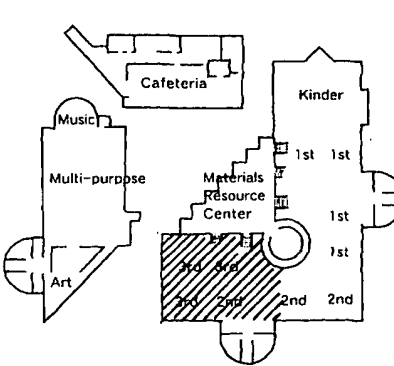

First Floor Plan (1/2500) $\operatorname{Map}(1 / 500)$

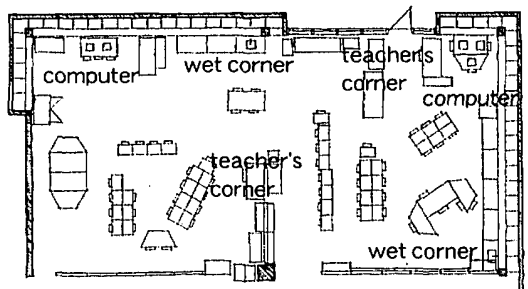

2nd grade CR Layout Map (1/400)

図 4 70年代のオープン型ユニットの事例 


\section{4.オープン型ユニットの事例}

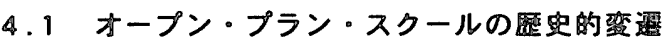

1960年代後半に英国のインフォーマル教育が米国に紹介される と、当時の教育やカリキュラムの変革の動き（カリキュラムの柔軟 化、統合学習、個別化・個性化教育等の動き）と、建筑の技術的側 面であるシステムズ・ビルティングの普及とあわせて、オーブン・ プラン・スクールが1970年代に急増した。学校建築に関しては、英 国が小さなスペースを連続させて有機的な平面構成を模索していた のに対して、米国は工場のような大空間を用意して、家具などで適 宜スペースを確保する方法をとつた。しかしながら、70年代半ば頃 から、教育現場からプライバシーの欠如や騒音の問題、あるいは教 育効果に対する疑問などの指摘がなされるようになると、オーブ ン・プラン・スクールの建設は隇少し、多くの既存のオーブン・ブ ラン・スクールでも壁や間仕切りを復活させるようになった。

しかし、オーブン・ブラン・スクールの流れは消滅したわけでは なく、80年代以降もこの流れを継承しながら新しい方向性を模索す る学校がいくつか見られる。これらの学校の特徵は、かつての大規 模なオープン・ブランと異なり、オーブンではありながら、各クラ ススペースの領域の独立性を高めるために、空間の分節化を図った ものである。

\subsection{0年代の大規篹オープン型の現犾}

1970年代に建設されたオーブン・ブラン・スクールを 3 例調査で きた。いずれもスペース・フレームを使った大空間を特徵としてい るが、建設当時とは使わ扎方の異なる事例も見られる。

(9) Mt. Healthy Elementary School, Indiana, 1972 一体的な大空間の中に、pre K-1年生、2-3年生、4-6年生に分けら れた 3 つのクラスターを持つ。クラスターはスキッブフロアによる レベル差やフロアの向きのずれなど空間的な変化により、領域感を
作り出している。児童数が定員より少なく余裕があるため、コン ピュータコーナーやグルーブ学習用のコーナー、？クラス合同の講 義スペース、科学用スヘー一スなどが設けられている。設立当時より 今日に至るまで日常的に個人や数人のグルーブに分かれ、それでれ のペースで学習や作業が進めら扎る。各クラスター内では、学年や クラスを分けず、学習目標や興味の対象によって児童をグルービン グし、チーム・・ィーチングで各グルーブの指導を行うティーチン グ・ユニットという考え方を採用しようと試みている。

(10) Fodrea Community School, Indiana, 1973

2 層吹き抜けの学習センター（Material Resource Center）を中 心に、1階、2 階にオープンスペースが広がる。クラスの領域を固 定しないワンルームであるにもかかわらず、各クラスは衝立や収納 家具などにより明確な領域を形成している。机の配置もグルーブを 形成するというよりは個人机を整然と配列する傾向を示す。教育 ステムそのものの見直しとともに、システム天井で露出していたス ペースフレームを隠し、照明設備もリニューアルするなど、校舎に も手を加えている。近い将来にはクラス間に壁の設置も計画するな ど、当初のオープンスクールの理念を時代に併せ変更している事例 である。チーム・ティーチングも行わ扔が、同学年間が中心で、 学年を越えた活動はほとんどされていない。

(ii) Glenville Elementary School, Connecticur, 1975

校舎は建設当初は大空間のオーブン・ブランであったが、以降安 定したクラスルームを確保したいという教師側からの希望でリニュ2 ーアルを行い、現在では叮動間仕切りでオープンスペ-ース左分割し ている。レイアウトを採取した 2 年生の 2 クラスは一体化して挍 り、日常的にチーム・ティーチングが展開されるが、両スベースに 教師コーナ゙ーをセットし独立した授業の展開も可能である。モジュ ラーユニットによるシステム家具を導入している。巟童の $15 \%$ ほ上゙

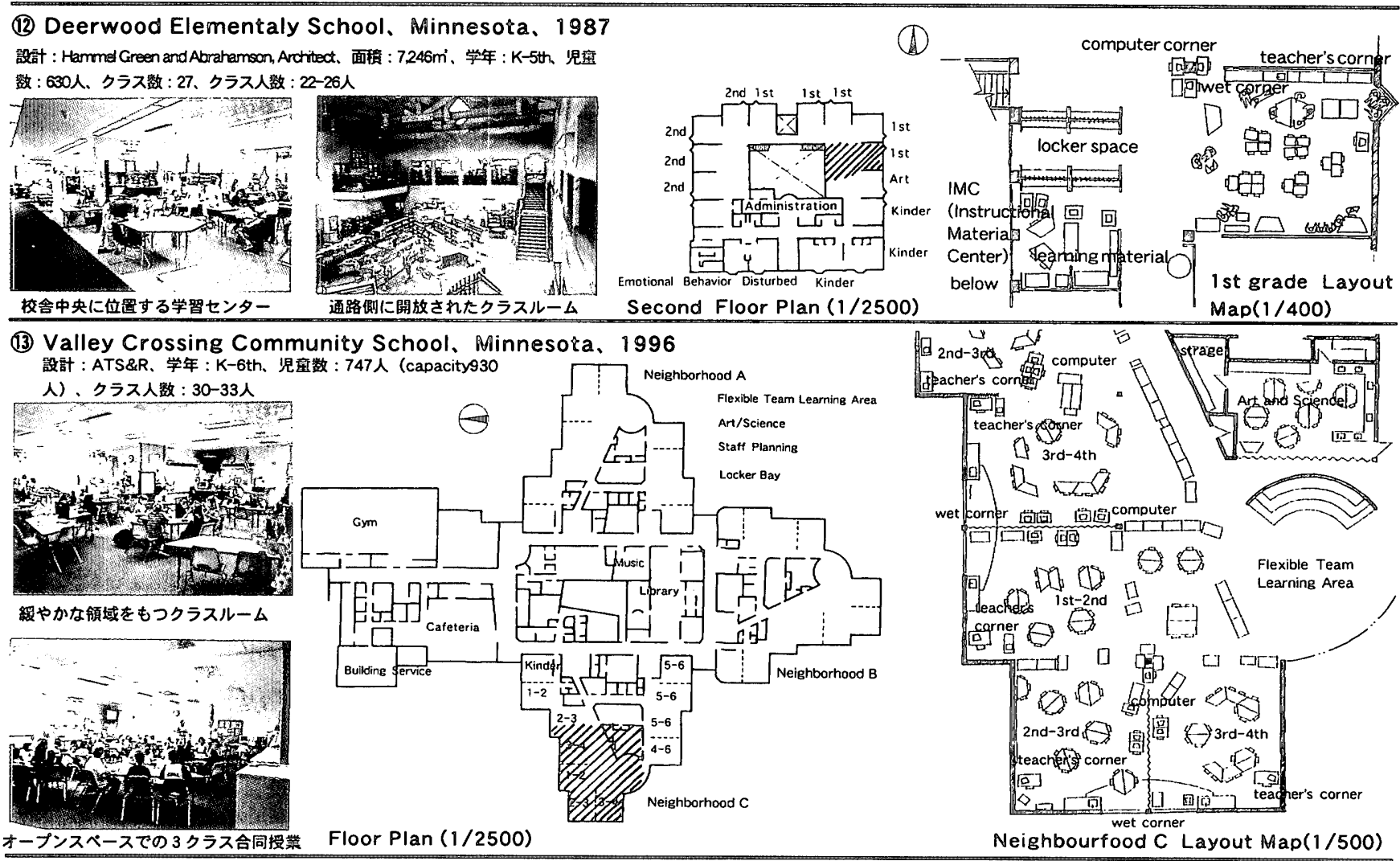

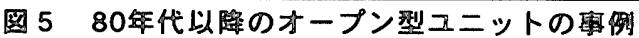


がマイノリティーであり、これに関連してPTA組織や地域組織が学 校内での様々な文化活動をサポートしている。

\subsection{0 年代以降の分節オープン型の事例}

80年代以降、オーブンな学習空間を確保しながらも、クラスの独 立性を確保できる緩やかな領域を形成しようとするオープン・ブラ ンがみられる。

(12) Deerwood Elementaty School, Minnesota, 1987

IMC ( Instructional Material Center) と呼ばれる吹抜の学習セン ターを中心に、四方 2 フロアーにわたりクラスルームが取り巻くコ ンパクトな平面構成である。各クラスルームはIMCに対してオーブ ンな形で配置されている。クラスルームにはシステム家具により教 師コーナーやウェット・コーナ゙ーが設けられている。隣接するクラ スルーム間は固定された壁で区切られているが、IMC側のオーブ ン・スペースは、学習コーナーや教材コーナー、ロッカー・スペー スなどとして利用されている。

特殊教育が充実していることが特徴であり、学贸障害児、情緒障 害児、あるいは英語を母国語としない児童、優れた才能をもつ览童 など子どもの個々の背景をすくい上げそれにふさわしい教育ブログ ラムを展開している。こうした児童は、1 日の半分は通常のクラス に合流する通級制度をとっている。

(13) Valley Crossing Community School, Minnesota, 1996

Neighborhoodと呼ばれる小さな学校（schools within a school）が 3つ集まり 1 つの学校を構成している。Neighborhood はいずれもK-6年生の学年構成であるが、クラスはノン・グレード で編成されている。平面的には各々教師スペースと美術/科学室を 中央コアとして周辺に固定的な間仕切りのない11のクラスルームが 取りついている。クラススペースに隣接するオープン・スペース と、neighborhood共通のFTLA ( Flexible Team Learning Area) と呼ばれるスペースを持つ。クラスの領域はアコーディオン・カー テンや収納家具で適宜仕切られ、緩やかな独立性が保たれている。 78名の教師は、この新しいタイプのオーブン・スクールを機能させ るために $1 \sim 2$ 年の任期で雇われている経験者で、徐々にレギュラ 一の教師に入れ替えていく予定である。

\section{2 オープン型ユニットの使われ方の特徽}

設立当初工場のような大空間でスタートした 70 年代の大規模オー プン型の現状と、オーブンでありながら空間的な分節がされた 80 年 代以降の分節オープン型の事例を取り上げた。大規模オーブン型で は、 20 年以上の時間を経て今なお当時の理念を継続している事例

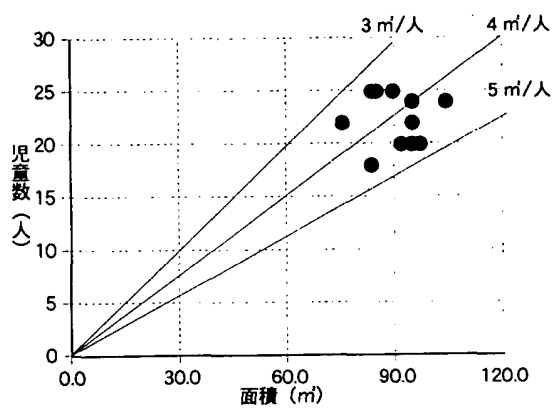

图 6 クラスルームの規模と密度
と、教育上クラス単位の学習活動を重視の方向に軌道修正しながら 建築的には可動間仕切りやシステム天井を導入する例が見ら报た。 80年代以降の分節オーブン型は、オーブン・ブランをベースにしな がらクラスの独立性あるいは領域性を最低限確保できるよう予め建 築的仕掛けを用意している事例といえよう。

いずれにしてもオーブン型においても、使わ扒方の現状としてク ラス集団がはっきり存在している。したがってそのクラス集団の帰 属の場としてのスペースも家具や可動間仕切り等で淡く囲いとら才 ている様子が観察された。その意味ではクローズド型と本質的な違 いは無いといえる。

\section{5. クラスルームの規模、形状、方位 \\ 5.1 クラスルームの規模}

クラスルームの面積水淮を知るために、領域が限定できるクロ一ズド型（8校15例）について児童 1 人当たりの床面積を調ベた（図 6）。ただしユニット内の共有スペースは含まない。

1 クラスルーム当たりの面積は、最小 $75.5 \mathrm{~m}^{2}$ から最大 $104.4 \mathrm{~m}^{2}$ と、 格差が大きい。 $80 \mathrm{~m}^{2}$ 越えるクラスルームが15例中13例あり、こう した大型のジスルームが例外的でないことが予想される。1クラ ス当たりの児童数は、18人から 25 人で、日本の 1 クラス定員 40 人の 6〜5割以下である。

児童 1 人当たりのクラスルーム面積を算出すると、大きいところ では $5 \mathrm{~m} / 人 の$ 水淮に匹敵し、小さいところでも $3.3 \mathrm{~m}^{2} / 人 の$ 水準で 学校により差り大きさが目立つが、概极 $4 \mathrm{~m}^{2} /$ 人が平均である。2 $\mathrm{m} /$ 人に満たない日本の事情（例えば $7.2 \mathrm{~m} \times 9 \mathrm{~m}=64.8 \mathrm{~m}^{2}$ の教室に 40 人とすると $1.62 \mathrm{~m}^{2} /$ 人となる）と比較すると、いかにゆったりし たクラスルームを用意しているかがわかる。 $4 \mathrm{~m}^{2} / 人 の$ 水準は日本 ではクラスルームに加え、クラスルームの1.5倍に等しい多目的人べ 一スを加えた場合の数值に当たる。また、クラス当たりの照童数が 少人数であることに加え、担任教師のほかにアシスタントの教師 や、ボランティアの親な上゙複数の大人が児童を補助をすることが日 常的であることを考えると、日本の状況と比較して面積的余裕や子 どもに対するケアの度台の違いはいかにも大きい。

\section{2 クラスルームの形状}

クラスルームの形状に着目すると、日本ではみら扒ない形状があ る。1クラス独立型のうちDCrow Island はワークスベースを附属 したL字型平面とすることで、各教室占有の外部空間を作りだしてい る。(2)6 to 5 Early Childhoodではクラスルームは 1 辺50mの正方 形校舎の 4 隅に配され、矩型を対角線で 2 分した三角形である。対 角線上の隔壁は可動で、場台によっては矩型の教室として使用可能 であるが、採集した事例:むあくまでも三角形教室として使用してい る事例である。

共有スペースを隣接する(6)Heathcoteでは、六角形のクラスルー ムが星形のコモンスペースに隣接するきわめて特異な平面形在形成 する。六角形は円形に近く、教室内の方向性が曖昧である。? Vintonはやはり 4 教室がコモンスペース在取り囲むが、雁行して隣 接する矩型の 2 教室が、接線で斜めに切ら扎変形したら角形となっ ている。2クラスー体型の!5)Southwood Glenも同様の例である。

基本的には矩型が主流であると考えられるが、限られた事例であ りながらこのように様々な平面形態がみら犺だ9 


\section{3 クラスルームの汸位}

日本では、特別な設計条件がない限りクラスルームを南面させる ことが配置計画上饾先的に行われる。クラスルームの面する方位と いう視点で調萓事例を眺めてみると、各クラスルームを一律に同一 方位に配置している事例が見当たらない。

中でも (1)Crow Island は全ての教室が南面する開口部を有する唯 一の例であるが、南北軸上にクラスルームを配置している点や、南 北軸を対称軸としてL字型のクラスルーム平面が東西対称になったウ イングもあり、南面配置を最俊先しているとは考えられない。同様 にフィンガー・ブランである (3)L.Frances Smithや (6)Heathcote は 三方あるいは四方に校舎ウィングが伸びており、各クラスルームの 方位はまちまちである。(2)6 to 6 Early Childhoodや(12)Deerwood は校舎全体が矩型でありその四方に配置されたクラスルームの方位 はやはり一定ではない。

(5)Southwood Glen や (7Vinton あるいは (8)Rawson の様に共通 スペースで棈成された中央ソーンの両サイドに配置されたクラスル 一ムは、方位が逆転している。

方位に関しては、空調が一般的に用いられない1940年代以前はと もかく、最近は全館空調が前提になっていることが多く、クラスル 一ムの空調が一般的ではないわが国とは事情が異なる。しかも気象 条件の異なる西部や南部の事例を久いているため、一概に言えない か゚、少なくとも調查筑囲ではクラスルームに関する南面配置の制約 が緩やかであり、したがって全体計画の自由度が高い。

\section{6. 济と的}

米国に拈けるクラスルームとユニットに関して、その多様な展開 の試みを13校の小学校の現地調查から分析を行ってきた。以上を要 約すると以下の通りである。

1) クラスルームのユニットは、クローズド型（共有スペースのあ るタイプとないタイプが存在する）とオープン型に分類できる。さ らに、クローズド型には 1 クラス独立型、2 クラス一体型のクラス ルームがあり、オープン型は大規模オープン型と分節オープン型に 分類できる。

2) クローズド型のうち共有スペースをもつ事例では、クラス単独 の㞄営を維持しつつ、蕧数クラスで共有するスペースと活動を可能 としている。共有スペースを持たない事例では、クラスルームもし くは隣接させて学習や生活に対するスペースを確保している。

3）オープン形ユニットには、70年代の大規模オープン型と 80 年代 以降の分節オーブン型がみられる。大規模オープン型では建築的に 手を加え時代に対応したり、分節オーブン型ではクラスの帰属スペ 一スを最低限確保するなど、クラス集団の存在という点で本質的に はクローズド型と遠いはない。

4）クラスルーム内および共有スペースには、デスク・ワークのコ 一ナーを中止に多様な学習コーナーが形成されている。

5 ）クラスルームの面㘔は、 $75.5 \mathrm{~m} \sim 104.4 \mathrm{~m}^{2}$ 、クラスの児童数は 18 人〜 25 人、児童 1 人あたりの面穦は $3.3 \mathrm{~m}^{2} /$ 人〜 $5.0 \mathrm{~m}^{2} /$ 人であり、 日本と比渂して余裕がある。

6) クラスルームの平面形状には、矩型のみでなく 3 角形、4 角

形、5 角形、6 角形、L字型などの変形型が見られる。

6 ）クラスルームの方位に関しては、全館空調を前提に特定の方位
を意図しておらず、同じ学校でもクラスルームにより方位が異なる ことがしばしばある。

以上のように限定された調査事例ではあるが、米国において同時 代的に多様な学習スペースが併存している状況を、クラスルームの ユニットブランという側面から具体的に把握寸ることができた。旦 本では教育、建築の両分野において画一性の繁害が表面化して いると考えら打るが、米国での寒態通じて知ることのできる 多様性の中に潜在する可能性を大いに参考にすべきであろう。

なお、ここではクラススペースの視点から論じたが、学校平 面全体に関わる通史、歷史的観点からの変遷、あるいは時代背 景との関倸については別論文（投稿中）で詳細に扱っている。

注

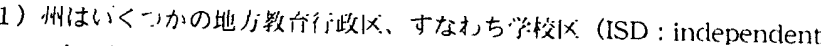

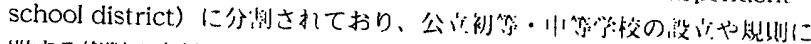

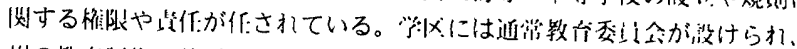

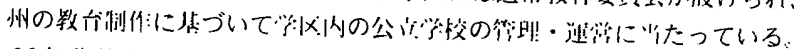

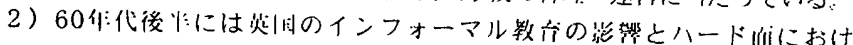
るシステムズ・ビルディングの箵及により、オーフン・フラン・ス

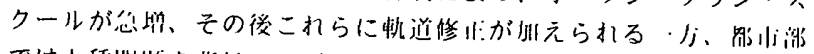

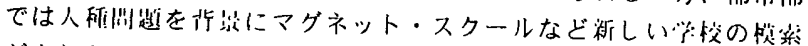

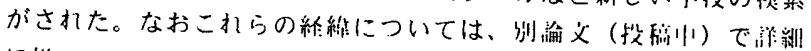
に扱つている。

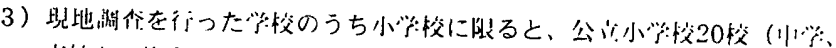

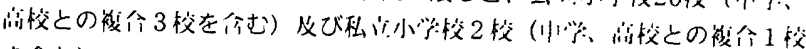

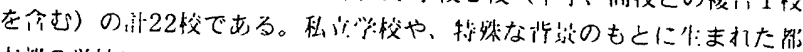
小激の兴校についてはこの分析刘嗮からは除外した。

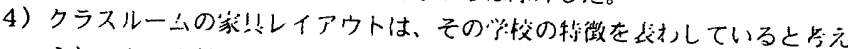

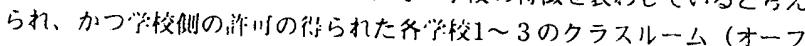

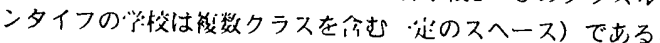

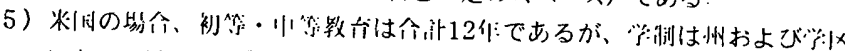

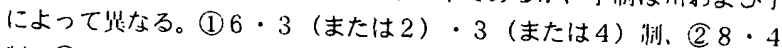

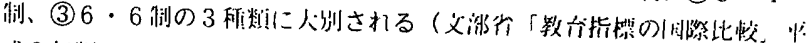
成 2 俳版に上る)。

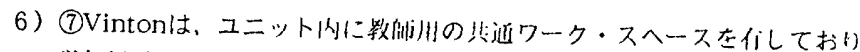

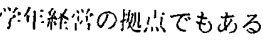

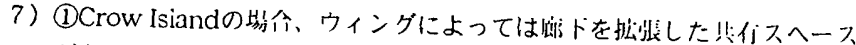
があり、范た、(5)SouthwoodGlenは、小さいながらもコモンと顺ぶアル

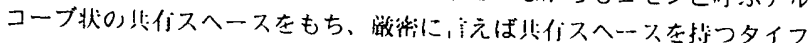

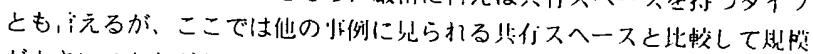

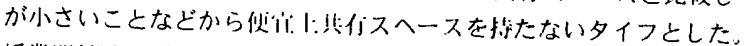

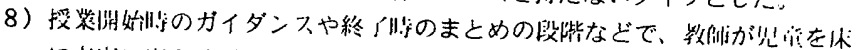

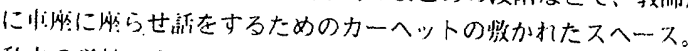

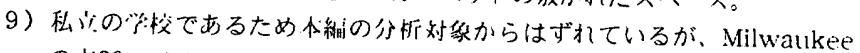
の战20マイル、Racine 刘外に仵们するPrairie School (Wisconsin,

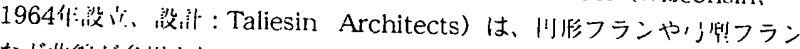

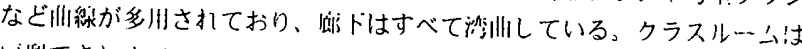

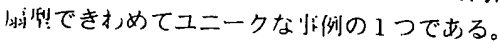

\section{竞调}

1) Graves,B.E., "SchoolWays",McGraw-Hill,Inc., 1993

2) "Educational Facilities. 1995-96 Review", ALAPress, 1996

3) Meek, A., "Design Places for Learning", CEFPL/ASCD, 1995

4) Dattner R.. "'Civil Architecture", McGraw-Hill,Inc., 1995

5) Korab B., "Columbus", Documan Press, 1989

6) "The Educational Facility PLanner. CEFPI Design Portfolio". CEFPI

7) "American School \& Lniversity Architectural Portfolio". American School \& Lnjversity ${ }^{r}$

8) "Learning by Design", The American School Board Journal 